\title{
Solar vanadium redox-flow battery powered by thin-film silicon photovoltaics for efficient photoelectrochemical energy storage
}

\author{
Félix Urbain ${ }^{1,4} \oplus$, Sebastián Murcia-López ${ }^{1}$, Nicole Nembhard ${ }^{1}$, \\ Javier Vázquez-Galván ${ }^{1}$, Cristina Flox ${ }^{1}$, Vladimir Smirnov ${ }^{2}$, \\ Katharina Welter ${ }^{2}$, Teresa Andreu ${ }^{1}{ }^{10}$, Friedhelm Finger $^{2}$ \\ and Joan Ramón Morante ${ }^{1,3}$ \\ ${ }^{1}$ IREC, Catalonia Institute for Energy Research, Jardins de les Dones de Negre 1, 08930 \\ SantAdrià de Besòs, Barcelona, Catalonia, Spain \\ 2 IEK-5 Photovoltaik, Forschungszentrum Jülich, D-52425, Jülich, Germany \\ ${ }^{3}$ Universitat de Barcelona, Martí i Franquès, 1, 08028 Barcelona, Catalonia, Spain \\ E-mail: furbain@irec.cat
}

Received 21 August 2018, revised 8 October 2018

Accepted for publication 23 October 2018

Published

\begin{abstract}
Solar-powered vanadium redox-flow batteries (VRFB) have emerged as an attractive alternative to large-scale and efficient energy storage and conversion. However, due to the stringent charging voltage requirements of vanadium-based systems (1.4-1.7 V), common photobatteries, applying standard photovoltaics with nonoptimized photovoltages, cannot be completely charged bias-free, i.e. by only using bias-free solar energy, or if they can be, only at unpractical low current densities of just a few $\mathrm{mA} \mathrm{cm}{ }^{-2}$. In response to this critical challenge, the present study aimed to design and test a compact device combining a highphotovoltage silicon multijunction solar cell with an all-vanadium continuous-flow battery. In particular, we applied a monolithic triple junction solar cell, which can provide photovoltage of up to $2.2 \mathrm{~V}$. Additionally, we have introduced the concept of increased illumination intensity for the solar VRFB. As a first demonstration, a complete bias-free solar charging at $25 \mathrm{~mA}$ $\mathrm{cm}^{-2}$ (300 $\mathrm{mW} \mathrm{cm} \mathrm{cm}^{-2}$ illumination) is reported. Moreover, we investigated the influence of the operation parameters of the redox-flow battery itself: the membrane type and the vanadium concentration in the electrolyte (i.e. storage capacity). The presented results provide evidence that the low-cost thin-film silicon based solar VRFB can be considered as an outstanding alternative for practical energy storage and conversion usage. A maximum bias-free solar conversion efficiency of $12.3 \%$ was achieved during charging, combined with promising and competitive energy efficiencies for the complete charge-discharge process that can guarantee an overall solar-to-electricity conversion efficiency of $>10 \%$.
\end{abstract}

Keywords: vanadium redox-flow battery, silicon, concentrated photovoltaics, energy storage, energy conversion

S. Supplementary material for this article is available online

\footnotetext{
${ }^{4}$ Author to whom any correspondence should be addressed.
}

\begin{tabular}{|lllll}
\hline JNL:JPD & PIPS: AAEAB9 & TYPE: SPE & TS: NEWGEN & DATE:2/11/18
\end{tabular}




\section{Introduction}

There is a worldwide commitment to working towards a sustainable and inclusive future; the efficient and large-scale storage of solar energy is considered a key challenge. It is vital that innovative and industrial scale storage solutions are channeled to circumvent the inherent intermittency of this renewable energy source. The utilization of solar energy in photoelectrochemical processes mimicking artificial photosynthesis, such as water splitting [1-3] or $\mathrm{CO}_{2}$ reduction [4, 5], presents an attractive way to store solar energy in the form of clean chemical fuels. However, the high cost of production and the subsequent storage and usage of these fuels, which is highly energy intensive and cannot draw upon infrastructures that are already available, has impeded the largescale implementation of such systems so far [6].

An alternative method is to store solar energy in the form of one or more dissolved electroactive species flowing through an electrochemical cell that, on charge, converts electricity (produced by a solar cell) into chemical energy, and on discharge converts chemical energy back into electricity, which can be used for domestic usage or to feed the grid. According to this principle, redox-flow batteries (RFB) store electrical energy and generate electricity by a redox reaction between electroactive ions dissolved in two electrolyte compartments (anolyte and catholyte) [7-9]. In the present study, we investigate all-vanadium redox-flow batteries (VRFB) for solar energy storage and conversion, as they offer several unique advantages compared to conventional battery types, such as lithium ion batteries. (i) Design flexibility: in general, RFB offer the advantage of decoupling the power output from the energy capacity. Whereas the power output is determined by the electrochemical cell stack size and number of cells, the energy storage capacity of the battery can easily be adjusted by the electrolyte properties; volume and vanadium concentration. As opposed to solid-state batteries, RFB therefore become more practical regarding large-scale systems [10]. (ii) Robust operation: in particular, VRFB alleviate the issue of cross-contamination during long-term operation because both the anolyte and catholyte contain the same element. This implies a quick response time, low self-discharge and a long life cycle [11-13]. (iii) High energy density: in comparison with other electrolyte solutions, VRFB operate at higher cell potentials $(>1.4 \mathrm{~V})$ and thus can reach higher energy densities than aqueous redox organic solutions, for instance [14].

This last point, however, induces a critical requirement for the applied solar cell in a solar-driven VRFB, especially regarding high photovoltage. Among the solar-driven VRFB reported thus far, no complete charging has been achieved due to the insufficient photovoltage provided by the applied solar cell, such as in CdS based systems [15], or if sufficient, only at impractical low vanadium concentrations $(0.01 \mathrm{M})$ and low current densities $\left(<0.04 \mathrm{~mA} \mathrm{~cm}{ }^{-2}\right)$, respectively, as for $\mathrm{TiO}_{2}$ based systems $[16,17]$. Toput into context the photovoltaic and battery characteristics, figure 1 shows the short-circuit densities $\left(J_{\mathrm{SC}}\right)$ as a function of the open-circuit voltages $\left(V_{\mathrm{OC}}\right)$ of common solar cell types and links this data with the theoretical cell potential of a VRFB of $1.26 \mathrm{~V}$ (red vertical line in figure 1).

In spite of high current densities of up to $43 \mathrm{~mA} \mathrm{~cm}^{-2}$, the majority of the presented solar cell types cannot provide enough photovoltage to enable unassisted solar charging of a VRFB $\left(V_{\mathrm{OC}}<1.26 \mathrm{~V}\right)$. Only III-V semiconductors (GaInP and other multijunction cells) and multijunction thin-film (TF) silicon solar cells possess adequate $J-V$ characteristics for integrated solar VRFB systems. Such compact design solutions utilizing monolithic solar cells earn a high usage flexibility compared to devices which apply solar modules connected in series (for higher photovoltages) and thus, suffering from design constraints and additional processing steps, e.g. laser scribing and solar tabbing wire connection. Nevertheless, real systems losses, e.g. overpotentials, low ionic conductivity, kinetic losses, cause the operation point (theoretically at $1.26 \mathrm{~V}$ ) to shift toward a more positive bias (1.6-1.7 V), as implied in figure 1. Hence, GaInP and tandem junction TF silicon (aSi/aSi) solar cells also might not produce enough voltage to be combined with VRFB. As multijunction III-V semiconductors are expensive, triple junction TF silicon ( $\mathrm{aSi} / \mathrm{aSi} / \mu \mathrm{cSi})$ cells appear to be the best solution for solar VRFB, especially if the characteristics of earthabundance, low material consumption (absorber layer thickness sequence $80 \mathrm{~nm} / 160 \mathrm{~nm} / 2 \mu \mathrm{m}$ ), light-weight, low-cost production, facile large-scale deposition and good photovoltaic characteristics (fill factors of around 72\%) are considered. Although, the multijunction configuration with three distinct absorber layers (earning different band gap energies) absorbs a wide spectrum of wavelengths of the incoming light [22], the achievable current densities lie around 8-9 $\mathrm{mA} \mathrm{cm}^{-2}$, and thus, are below commercially applied current densities for VRFB [25]. In order to increase the operation current density and circumvent the need to increase the battery electrode areas, which would introduce a supplementary cost factor, we introduce the concept of increased illumination intensity. With this approach, we exemplarily show that current densities of $25 \mathrm{~mA} \mathrm{~cm}{ }^{-2}$ can be achieved with the silicon TF triple cell (at $300 \mathrm{~mW} \mathrm{~cm}^{-2}$ illumination), which enabled solar charging of VRFB with industry-viable specific storage capacities of up to $21.44 \mathrm{Ah}^{-1}$ and power densities of up to $27 \mathrm{Wh}^{-1}$ at reasonable charging times. Additionally, we analyze the influence of operation parameters of the RFB itself, i.e. membrane type and vanadium concentration in the electrolyte. Our findings show that the presented solar VRFB can exhibit energy efficiencies of up to $77 \%$ for the complete charge-discharge along with solar energy conversion efficiencies of up to $12 \%$.

\section{Experimental}

\subsection{Preparation of thin-film silicon solar cell and battery components}

The details regarding the preparation of the triple junction TF silicon solar cell can be found in [22]. The amorphous (a-Si) and microcrystalline $(\mu \mathrm{c}-\mathrm{Si})$ absorber layers were deposited using the plasma enhanced chemical vapor deposition 


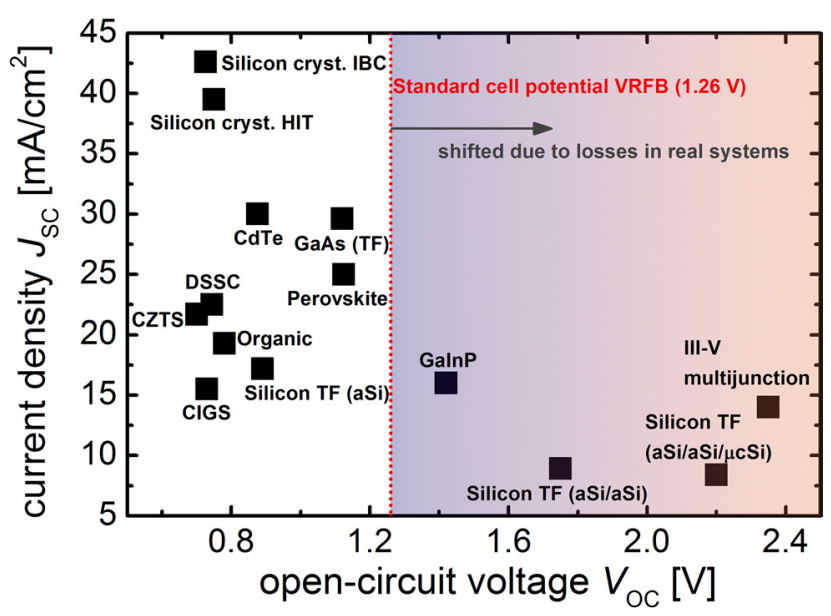

Figure 1. Short-circuit current densities $\left(J_{\mathrm{SC}}\right)$ and open-circuit voltages $\left(V_{\mathrm{OC}}\right)$ of common solar cell types linked with the theoretical operation point of a VRFB device at $1.26 \mathrm{~V}$ (red dashed vertical line, without overpotential losses). Solar cell parameters of Si IBC, GaAs, CIGS, CdTe, CZTS, perovskite, DSSC, and organic can be found in [18]. Information on Si HIT, aSi, aSi/aSi, $\mathrm{aSi} / \mathrm{aSi} / \mu \mathrm{cSi}$, III-V, and GaInP can be found elsewhere [19-24]. In real solar VRFB devices this operation point is shifted due to overpotential losses, indicated by the grey arrow.

technique in a multichamber system. The TF silicon solar cell was made in a stacked $\mathrm{p}-\mathrm{i}-\mathrm{n}$ superstrate configuration with a sputtered aluminum doped zinc oxide/silver ( $\mathrm{ZnO}: \mathrm{Al} / \mathrm{Ag}$ ) reflecting rear contact, defining the area $\left(1 \mathrm{~cm}^{2}\right)$ of the individual cells [26].

For the VRFB, positive and negative electrodes were made of rayon-based carbon felt with a thickness of $6 \mathrm{~mm}$ (Carbon Lorraine). The geometrical area of the as-prepared electrodes was $2 \mathrm{~cm}^{2}$. For the positive electrode a plasma treatment was conducted and for the negative electrode hydrogen treated $\mathrm{TiO}_{2}$-based felt was applied (see [27] for more details). Vanadium oxide sulfate $(\geqslant 99.9 \%)$ was obtained from Sigma Aldrich and sulfuric acid (95\%-98\%) was obtained from Labkem. The electrolytes were prepared by dissolving $0.2,0.5$, 1 , and $1.6 \mathrm{MVOSO}_{4}$ in $3 \mathrm{M} \mathrm{H}_{2} \mathrm{SO}_{4}$ solutions. Subsequently, the corresponding anolytes and catholytes were electrogenerated starting from $\mathrm{VO}^{2+}$ species in both reservoirs. For the charge, $40 \mathrm{ml}$ of catholyte and $20 \mathrm{ml}$ of anolyte solution were used, while purging nitrogen to the anolyte solution to minimize self-oxidation of the active species. After the charging process was completed, $20 \mathrm{ml}$ of the as-prepared $40 \mathrm{ml}$ of $\mathrm{VO}_{2}^{+}$was removed from the catholyte solution, meanwhile the $20 \mathrm{ml}$ of the as-prepared $\mathrm{V}^{2+}$ anolyte solution was left unchanged. By doing so, the discharge was started with $20 \mathrm{ml}$ of catholyte $\left(\mathrm{VO}_{2}^{+}\right)$and anolyte $\left(\mathrm{V}^{2+}\right)$, respectively. Consequently, after complete discharging, $20 \mathrm{ml}$ of $\mathrm{VO}^{2+}$ and $\mathrm{V}^{3+}$ were obtained, which served as the starting catholyte and anolyte solutions for the solar VRFB tests, respectively.

\subsection{Solar VRFB setup and characterization}

The solar VRFB performance was assessed using a flow cell system that was designed in-house, which is schematically shown in figure 2(a) and has been adapted based on designs previously published by our group [28-31]. As depicted in figure 2(a), the device was assembled by 'sandwiching' the membrane (Nafion ${ }^{\circledR} 117$, Nafion ${ }^{\circledR} 115$, Bipolar FUMASEP, Selemion AMV AGC Engineering, Zirfon Perl AGFA, all with the dimensions of $4 \mathrm{~cm} \times 6 \mathrm{~cm}$ ) between the two carbon felt electrodes (positive and negative) with an area of $2 \mathrm{~cm}^{2}$ and two current collectors made of graphite SGL CARBON Grade $\mathrm{R} 8710$. The characteristics of the used membranes are summarized in the supplementary information in table S1 (stacks.iop. org/JPhysD/00/0000/mmedia). Viton ${ }^{\circledR}$ gaskets were placed in between each of the aforementioned components in order to avoid leakage of the electrolytes. At both ends of the battery, metallic aluminium endplates were mounted. The TF silicon solar cell was attached to one of the metallic aluminium endplates and electrically connected to both current collectors by wiring. The complete solar VRFB was tested using catholyte and anolyte reservoirs of $5 \mathrm{ml}$, respectively, which were connected to the battery by tubing of $1.6 \mathrm{~mm}$ in diameter.

(Photo)electrochemical measurements were conducted using a Biologic ${ }^{\circledR}$ VMP-3 multipotentiostat controlled by EC-lab ${ }^{\circledR}$ software. The flow rate at each side was kept constant at $35 \mathrm{ml} \mathrm{min}{ }^{-1}$, while continuously purging the negative reservoir with nitrogen (the same as for the electrogeneration). The flow cell was charged up to $1.7 \mathrm{~V}$ and then discharged to $0.7 \mathrm{~V}$ at different current densities, depending on the light intensity used for illumination (100, 200, and 300 $\mathrm{mW} \mathrm{cm}{ }^{-2}$ ). Complete charge and discharge, i.e. the state-ofcharge of the vanadium solutions, was deduced based on the particular color changes of the oxidized and reduced vanadium solutions, respectively (as shown by the photographs in figure 2(b)) [32]. A solar simulator equipped with a $150 \mathrm{~W}$ xenon lamp was used as the light source. The intensity of the light source was adjusted to match standard sunlight conditions at $100 \mathrm{~mW} \mathrm{~cm} \mathrm{~cm}^{-2}$ as well as concentrated illumination conditions of 200 , and $300 \mathrm{~mW} \mathrm{~cm}^{-2}$ intensity, respectively, by varying the solar VRFB-simulator distance. The performance evaluation method for the VRFB single cell was determined by measuring the cell potential versus time, from which the following efficiencies could be deduced: (1) Coulombic efficiency $(\mathrm{CE})$, i.e. the ratio of the average discharging capacity to the average charging capacity, (2) voltage efficiency (VE), i.e. the ratio of the average discharging voltage to the average charging voltage, (3) energy efficiency (EE), i.e. the product of EE and VE, and (4) the electrolyte utilization (EU), i.e. the ratio between measured capacity during solar charging and the theoretical storage capacity of the given vanadium concentration. For the discharge we applied the same average current density as measured during the solar charging.

As shown in figure 2(b), the first step in the operation of the solar VRFB is the conversion of solar energy into electrical energy through a solar cell. In the second step, this energy is stored, i.e. used to drive the redox reaction producing a reduced $\left(\mathrm{V}^{2+}\right)$ and an oxidized $\left(\mathrm{VO}_{2}^{+}\right)$chemical species (charge), as depicted in figure 2(b). To generate electricity, i.e. to reuse the stored electrical energy, the resulting redox species can be readily oxidized $\left(\mathrm{V}^{3+}\right)$ and reduced $\left(\mathrm{VO}^{2+}\right)$, respectively (discharge). The corresponding reversible chemical reactions are as follows: 
a)

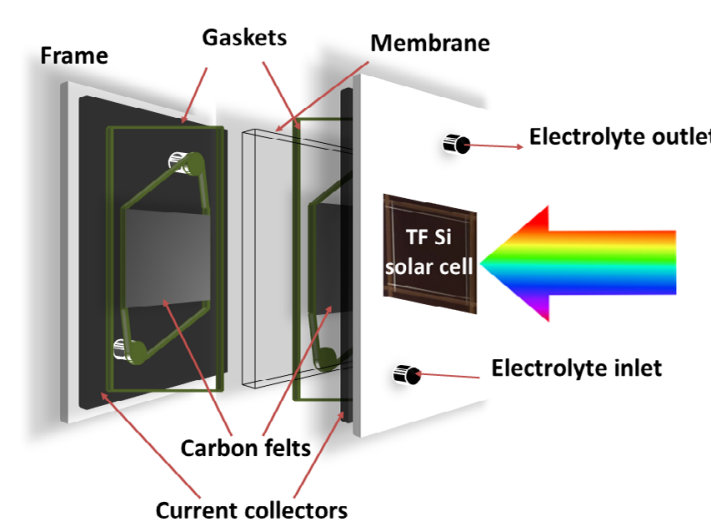

b)

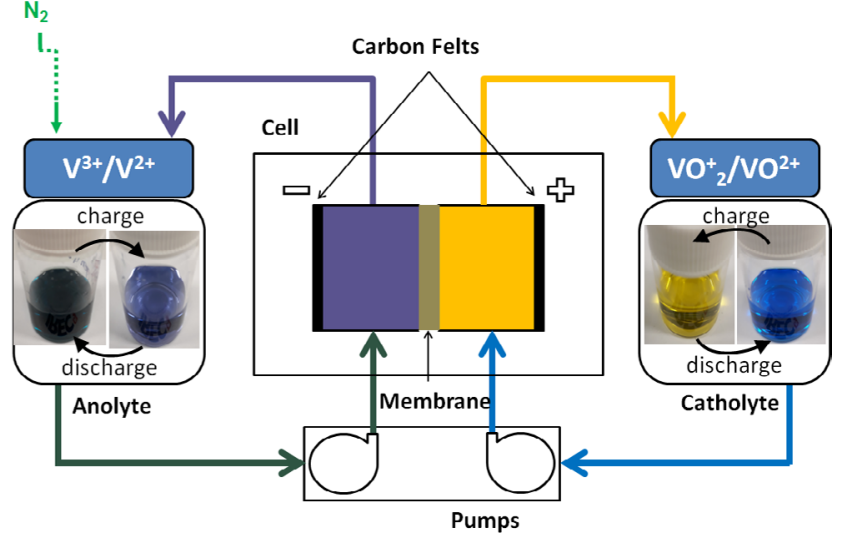

Figure 2. (a) Scheme of the solar VRFB setup showing the main components of the device. (b) Schematic drawing of the VRFB configuration illustrating the charge-discharge process.

Catholyte: $\mathrm{VO}^{2+}+\mathrm{H}_{2} \mathrm{O} \rightleftarrows \mathrm{VO}_{2}^{+}+2 \mathrm{H}^{+}+e^{-} \mid E^{0}=+1.0 \mathrm{~V}$ versus NHE

Anolyte: $\mathrm{V}^{3+}+e^{-} \rightleftarrows \mathrm{V}^{2+} \mid E^{0}=-0.26 \mathrm{~V}$ versus NHE

RFB: $\mathrm{VO}^{2+}+\mathrm{V}^{3+}+\mathrm{H}_{2} \mathrm{O} \rightleftarrows \mathrm{V}^{2+}+\mathrm{VO}_{2}^{+}+2 \mathrm{H}^{+} \quad \mid \Delta E=1.26 \mathrm{~V}$ versus NHE

where the water $\left(\mathrm{H}_{2} \mathrm{O}\right)$ and protons $\left(\mathrm{H}^{+}\right)$are required in the cathodic reaction to maintain the charge balance and the stoichiometry.

\section{Results and discussion}

\subsection{Membranes}

We initiated our study with the investigation of the influence of the utilized membrane on the performance of the solar VRFB. The membrane is a key component of the VRFB since it affects the efficiency, lifespan and cost of VRFB systems. Its main function consists of separating the positive and negative half-cell compartments, while providing high proton conductivity, low vanadium ion permeability, and ensuring high stability against the harsh acid and oxidation environment of vanadium electrolytes [33]. There have been tremendous efforts made by other groups regarding these stringent requirements. However, thus far, these studies have been conducted in view of high current operations $\left(>100 \mathrm{~mA} \mathrm{~cm}^{-2}\right)$ [34-38] and thus not dedicated toward solar-driven systems, which work in the low-current regime $\left(<30 \mathrm{~mA} \mathrm{~cm}{ }^{-2}\right)$. For this purpose, the present study aimed to assess the performance of conventional membranes also for solar VRFB. In order to assure reasonable charging times at $100 \mathrm{~mW} \mathrm{~cm} \mathrm{~cm}^{-2}$ illumination, i.e. low photocurrent densities $\left(<10 \mathrm{~mA}\right.$ for $1 \mathrm{~cm}^{2} \mathrm{TF}$ silicon solar cell), we started with $0.2 \mathrm{M}$ vanadium electrolytes to test different membranes. We selected Nafion 117, Nafion 115, Selemion, Bipolar, and Zirfon and conducted charging for $0.2 \mathrm{M}$ vanadium solutions under $100 \mathrm{~mW} \mathrm{~cm}{ }^{-2}$ illumination. Figure 3 shows the cell potential versus time measurements during charge for the investigated VRFB systems under $100 \mathrm{~mW} \mathrm{~cm}^{-2}$ illumination (1 sun).

As is apparent from figure 3 and expected from figure 1, the TF silicon solar cell provided enough photovoltage to completely charge all the tested VRFBs without any external applied bias, i.e. only by using sunlight energy. The average bias-free photocurrent density over the charging time was $8 \mathrm{~mA} \mathrm{~cm}^{-2}\left( \pm 0.1 \mathrm{~mA} \mathrm{~cm}{ }^{-2}\right)$. Table 1 presents the storage capacity and electrolyte utilization values for the tested membrane based VRFB, including the respective membrane thicknesses. Nafion type membranes, although relatively costly, are known to possess a high chemical stability along with high ionic conductivities $\left(2 \times 10^{-1} \mathrm{~S} \mathrm{~cm}^{-1}\right.$ for type 117) [34]. This implies a lower resistance of the membrane compared to other types, which was confirmed by our findings as the Nafion 117 and Nafion 115 provided the lowest starting charging voltages of all tested membranes. Furthermore, the Nafion 117 based solar VRFB achieved the highest storage capacity of $2.64 \mathrm{Ah} \mathrm{l}^{-1}$ for the tested $0.2 \mathrm{M}$ vanadium electrolyte $(5 \mathrm{ml}$ for each compartment) along with a high EU of $98.5 \%$. For the Nafion 115, the decreased membrane thickness (see last column in table 1) should straightforwardly reduce even more the membrane resistance. This was, however, only observable during the first two hours of charging, when the cell voltage of Nafion 115 was below that of Nafion 117 (see figure 3). After complete solar charging, the Nafion 115 membrane provided a lower capacity of $2.53 \mathrm{Ah} \mathrm{l}^{-1}$ than the Nafion 117 membrane, resulting in an EU of $88.6 \%$. This finding can be explained by the fact that thinner membranes suffer more from ion crossover and thus increasingly imbalance the electrolytes and reduce the electrolyte utilization efficiency during charging. Furthermore, it is well known that the crossover issue, i.e. $\mathrm{V}^{2+}$ permeation and thus, self-discharge, is even more pronounced for low current densities [35, 36], which might be the reason for the difference in the charging time for both Nafion membranes and, consequently, the EU of the complete process (see table 1).

Selemion, which is a hydrocarbon-type ion exchange membrane, was tested in this study because it exhibits a similar ionic conductivity to Nafion-based membranes [34] and is more cost effective than most other membrane types 


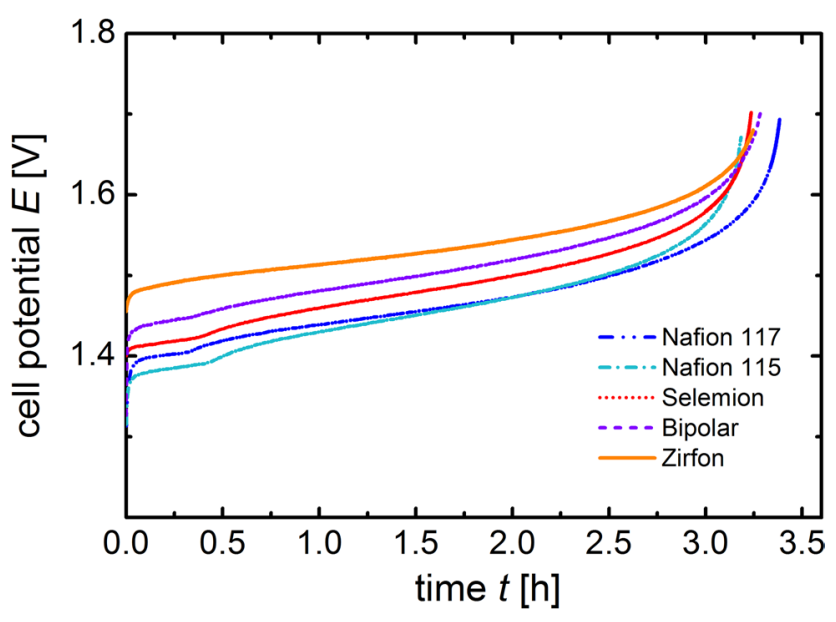

Figure 3. Charge performance of solar VRFBs applying different membrane types: Nafion 117, Nafion 115, Selemion, Bipolar, and Zirfon. A vanadium concentration of $0.2 \mathrm{M}$ was chosen for the experiment, along with a constant electrolyte flow rate of $35 \mathrm{ml}$ $\mathrm{min}^{-1}$. For the solar charge an average photocurrent density of $8 \mathrm{~mA} \mathrm{~cm}^{-2}$ was achieved under $100 \mathrm{~mW} \mathrm{~cm}^{-2}$ illumination intensity.

Table 1. Storage capacity and electrolyte utilization (EU) of the solar VRFB during charging using different membranes (with indicated thickness) at $100 \mathrm{~mW} \mathrm{~cm}^{-2}$ illumination and $0.2 \mathrm{M}$ vanadium concentration.

\begin{tabular}{llll}
\hline Membrane & $\begin{array}{l}\text { Capacity } \\
{\left[\mathrm{Ah}^{-1}\right]}\end{array}$ & $\begin{array}{l}\text { Electrolyte } \\
\text { utilization EU }[\%]\end{array}$ & $\begin{array}{l}\text { Thickness } \\
{[\mu \mathrm{m}]}\end{array}$ \\
\hline Nafion117 & 2.64 & 98.5 & 180 \\
Nafion115 & 2.53 & 94.4 & 125 \\
Selemion & 2.58 & 96.4 & 110 \\
Bipolar & 2.62 & 97.9 & 200 \\
Zirfon & 2.57 & 95.8 & 500 \\
\hline
\end{tabular}

[37]. Additionally, its anionic character might hinder vanadium crossover more than cationic Nafion membranes. The good ionic conductivity was confirmed by a good capacity after complete solar charging of $2.58 \mathrm{Ah}^{-1}$ and an EU of 96.4\% (see figure 3 and table 1). The slightly lower values compared to the Nafion 117 membrane presumably can be linked to the negative effects of the reduced thickness of the tested Selemion, as already mentioned for the Nafion 115 type. Nevertheless, in view of large-scale commercial applications for solar VRFB, this membrane type can potentially reduce system costs.

In order to reduce the permeation of vanadium ions during cycling of the battery, a bipolar membrane was tested. Although it is known that bipolar membranes exhibit higher membrane-derived voltage losses, they offer the advantage of stable complementary cathode and anode catalysis with stable (local) ion concentrations, and thus might reduce the problem of electrolyte imbalance. Indeed, the solar VRFB utilizing the bipolar membrane exhibited the second best charging capacity

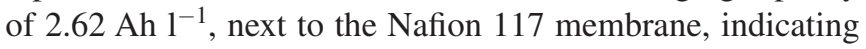
a stable charge behavior along with a good EU of $97.9 \%$ (see table 1). However, the charging voltage was significantly higher compared to the Nafion and Selemion, resulting from a higher membrane resistance. Zirfon as a separator membrane is usually applied for alkaline water electrolysis and microbial fuel cells [38], offering high robustness at reduced cost. Here, for the first time, Zirfon was tested for a solar VRFB system. The results from figure 3 show that Zirfon is not suitable as a membrane for VRFBs. Although a capacity of $2.57 \mathrm{Ah}^{-1}$ and an EU of over $95 \%$ were measured, the system provided a large overpotential (1.45 V starting charging voltage) compared to the other membrane types, which makes the tested system inadequate for commercial applications. The high resistance can be explained by its increased thickness $(500 \mu \mathrm{m})$ and the harsh acidic conditions of the solar VRFB operation, whereas the Zirfon can operate more efficiently in $\mathrm{pH}>7$ regimes. In total, it can be concluded that the Nafion 117 membrane provided the best capacity and electrolyte utilization values, which is why it was chosen for the following tests in this study. Nevertheless, it shall be noted that Selemion membranes offer a low-cost alternative to Nafion and might even reach the same performance under long-term operations. Prolonged chargedischarge cycling tests could not be assessed in the framework of this study, but are currently under investigation.

\subsection{Light intensity}

In view of a niche application opportunity for solar driven VRFB, operation current densities of below $10 \mathrm{~mA} \mathrm{~cm}^{-2}$ are not suitable for reaching the target power outputs required in indutry or domestic usage. In particular, if the aim is to lower the cost of solar electricity in the system, it is crucial to find ways to increase the photocurrent without expensive upscaling. The most efficient and straightforward method is to increase the available illumination intensity for the solar cell by light concentration. Concentration of sunlight onto photovoltaic cells, and the consequent replacement of the expensive photovoltaic area with less expensive designs, is seen as one efficient method to reduce the cost of solar electricity [39]. In figure 4(a), the effect of increased illumination intensity on the photovoltaic characteristics of the applied TF silicon solar cell is shown. We tested concentration factors of two and three, giving illumination intensities of 200 and $300 \mathrm{~mW}$ $\mathrm{cm}^{-2}$, respectively. Please note that the light concentration was achieved by moving the VRFB closer to the sun simulator and thus might introduce some small deviations from the exact concentration factors. Nevertheless, as can be seen from the $J-V$ curves in figure 4(a), measured under different intensities, the $J_{\mathrm{SC}}$ linearly increased with the light concentration factor (up to $26.4 \mathrm{~mA} \mathrm{~cm}^{-2}$ for $300 \mathrm{~mW} \mathrm{~cm}^{-2}$ ). The $V_{\mathrm{OC}}$ also slightly increased (up to $2.3 \mathrm{~V}$ at $300 \mathrm{~mW} \mathrm{~cm}^{-2}$ ), but is less sensitive to light intensity than the short circuit current. The value of the $V_{\text {OC }}$ depends much more on the internal structure of the solar cell, i.e. on the phenomena of recombination and conduction [40]. In fact, $V_{\mathrm{OC}}$ is defined by the splitting of the quasi-Fermi levels under illumination, which increases upon illumination intensity, i.e. in the presence of more photogenerated charge carriers [41]. The fill factor slightly decreases for higher intensities of irradiation due to the influence of series resistance in the solar cell device [41]. Figure 4(a) additionally depicts the VRFB cell voltage range, in which the solar cell will be operated during charging, which can be estimated to lie between $1.4 \mathrm{~V}$ to $1.7 \mathrm{~V}$. Consequently, this illustration enables us to 
a
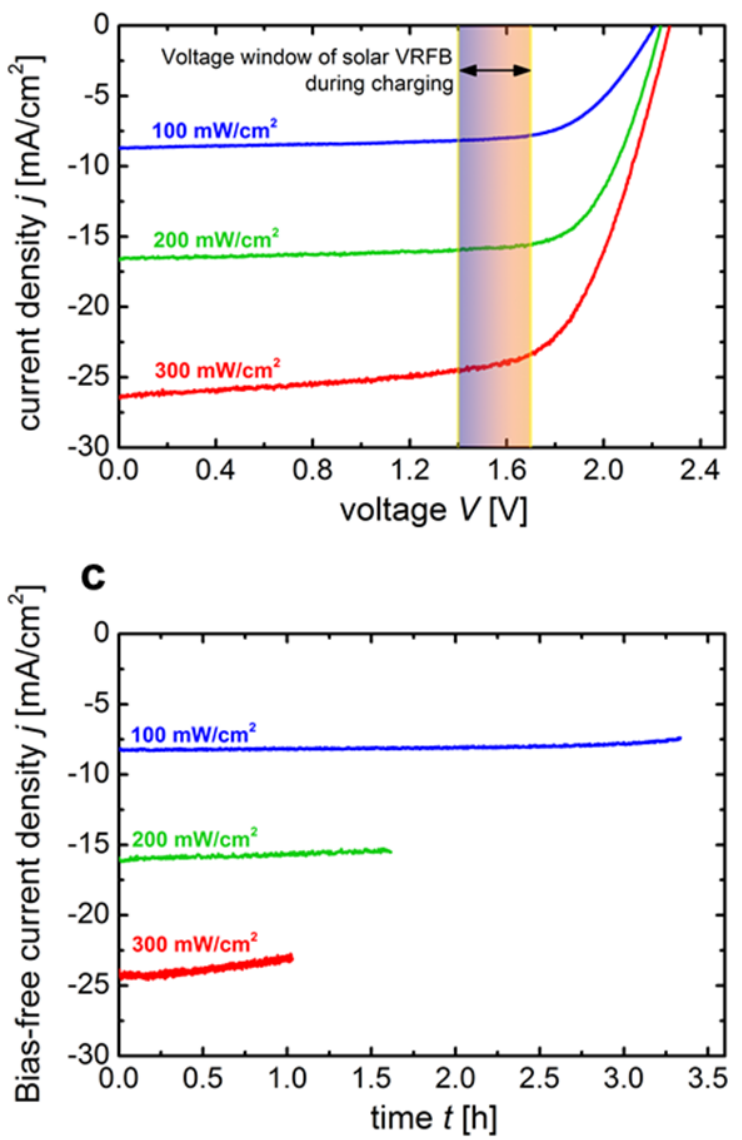

b

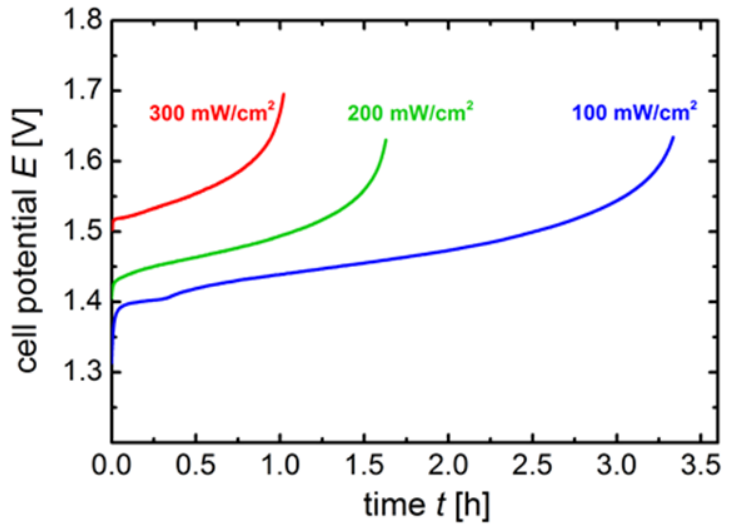

Figure 4. (a) Current density-voltage curves of the applied TF silicon solar cell for different light intensities: 100, 200, and $300 \mathrm{~mW} \mathrm{~cm}^{-2}$. The colored bar indicated the cell voltage window of the VRFB during the charging process. (b) Charge performance of solar VRFBs operated under different light intensities. A vanadium concentration of $0.2 \mathrm{M}$ was chosen for the experiments, along with a constant electrolyte flow rate of $35 \mathrm{ml} \mathrm{min}{ }^{-1}$. (c) Current densities provided by the solar cell during charging for the different applied illumination intensities.

deduce the expected maximum solar charging current densities in the solar VRFB configuration. The fact that the conventional VRFB voltage range lies very close to the maximum power point of the TF silicon solar cell (see figure 4(a)), even after light concentration, further confirms the efficient and adaptable coupling of VRFB with TF silicon photovoltaics for efficient bias-free solar charging. Temperature effects of increased illumination intensity were not investigated within this study, but will be explored in upcoming works. In fact, like all semiconductor-based devices, the investigated solar cell is sensitive to temperature variations, which may also contribute to changes in the current density. The influence of the temperature on the performance of the applied triple junction solar cell has been investigated in more detail in [42]. The power density versus voltage plots of the TF silicon solar cell under varied illumination intensity can be found in the supplementary information in figure $\mathrm{S} 1$.

Figure 4(b) shows the solar charging curves of the solar VRFBs using $0.2 \mathrm{M}$ vanadium electrolytes and operated under different light irradiation conditions. Two distinct observations can be made: firstly, as expected, the charging time decreased with increasing light intensity, i.e. increasing current density. Complete charging was achieved after 3.3,
1.6 , and $1.0 \mathrm{~h}$ for 100,200 , and $300 \mathrm{~mW} \mathrm{~cm}{ }^{-2}$, respectively. Secondly, as a consequence of the higher current density, the cell overpotential increased. Cell charging voltages started at $1.38 \mathrm{~V}$ for $100 \mathrm{~mW} \mathrm{~cm}^{-2}, 1.44 \mathrm{~V}$ for $200 \mathrm{~mW} \mathrm{~cm}^{-2}$, and 1.51 $\mathrm{V}$ for $300 \mathrm{~mW} \mathrm{~cm}{ }^{-2}$. The achieved bias-free photocurrent densities during charging are plotted in figure 4(c), showing that average photocurrent densities of $8 \mathrm{~mA} \mathrm{~cm}{ }^{-2}, 15.5 \mathrm{~mA}$ $\mathrm{cm}^{-2}$, and $23.5 \mathrm{~mA} \mathrm{~cm}{ }^{-2}$ were measured for 100, 200, and $300 \mathrm{~mW} \mathrm{~cm}{ }^{-2}$ illumination intensity. These currents correlate very well with the currents estimated from figure 4(a), which confirms the statements made above with respect to estimating the operation photocurrent density in solar-driven VRFB. In total, these findings confirm that concentrating light is an effective method to increase the operation current density for unassisted solar-driven VRFB. Furthermore, the availability of higher photocurrent densities will eventually allow us to increase the vanadium concentration and thus the energy storage capacity of the solar VRFB.

\subsection{Vanadium concentration}

In VRFB, or RFB in general, the storage capacity and energy density of the system are directly linked to the active species 


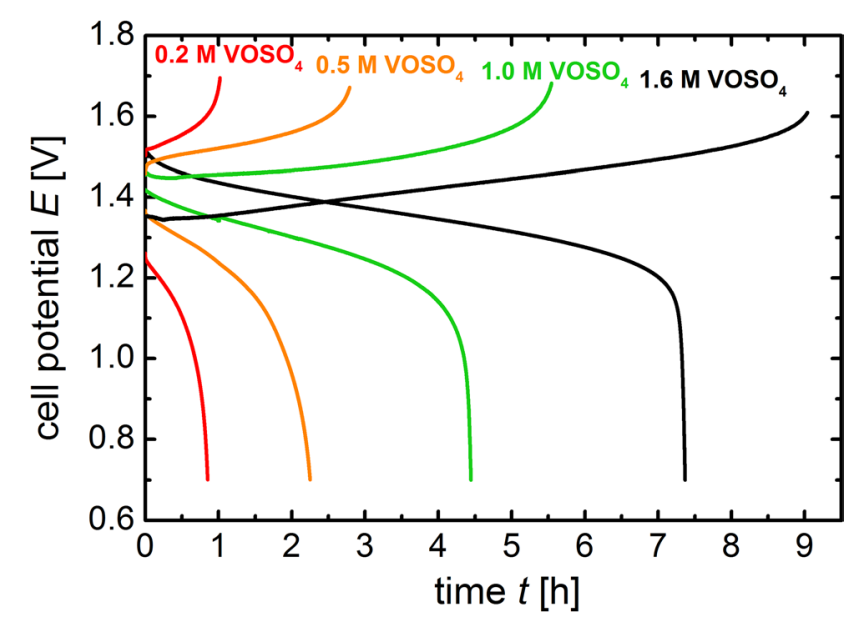

Figure 5. Charge-discharge performance of the solar VRFB as a function of the vanadium concentration. The illumination intensity was $300 \mathrm{~mW} \mathrm{~cm}^{-2}$ for all investigated devices along with an average charging photocurrent density of $23.5 \mathrm{~mA} \mathrm{~cm}^{-2}$, which was also applied for the discharge processes. The electrolyte flow rate

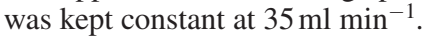

in the electrolytes. Vanadium concentrations of $0.2 \mathrm{M}$ are very different to practical electrolyte concentrations, which usually lie around 1.6 M [32 43, 44], which corresponds to a theoretical specific storage capacity of $21.44 \mathrm{Ah}^{-1}$ and an energy density of $54 \mathrm{Wh}^{-1}$. Therefore, we investigated the influence of increased vanadium contents on the complete round trip solar VRFB performance and tested $0.5 \mathrm{M}, 1 \mathrm{M}$, and $1.6 \mathrm{M}$ under $300 \mathrm{~mW} \mathrm{~cm}^{-2}$ illumination intensity using Nafion 117 as membrane. Figure 5 shows the charge-discharge behavior of the solar VRFB under $300 \mathrm{~mW} \mathrm{~cm} \mathrm{~cm}^{-2}$ irradiation intensity for the different vanadium contents. An average charging photocurrent density of $23.5 \mathrm{~mA} \mathrm{~cm}^{-2}\left( \pm 0.1 \mathrm{~mA} \mathrm{~cm}^{-2}\right)$ was measured for all solar VRFB (similar to the result in figure 4(c)) and applied for the respective discharge sequences by means of a potentiostat. The latter implies that the discharge of the solar VRFB was simulated and thus might slightly differ from a complete solar charge-discharge process.

Nevertheless, the results presented in figure 5 confirm that the thin-film silicon-based VRFB can effectively be charged up to industry-relevant vanadium concentrations of 1.6 $\mathrm{M}$ by using the solar energy as the only energy input and thus demonstrate its feasibility for commercial applications. The results of the efficiency evaluation based on the charge (solar)-discharge (simulated) curves in figure 5 are presented in table 2 . The CE values only slightly varied among the tested vanadium concentrations, showing the lowest value of $78.4 \%$ for the $0.2 \mathrm{M}$ and the highest values of $82.3 \%$ and $81.3 \%$ for the 0.5 and $1.6 \mathrm{M}$ solutions, respectively. Such small changes are understandable as the bias-free charging current density was kept constant (slight variations due to differences in cell potential taken into account through the error of $0.1 \mathrm{~mA} \mathrm{~cm}^{-2}$ ) for all the measurements and thus the kinetics of the process were only marginally affected.

In contrast, VE was very sensitive to an increase in the vanadium concentration and significantly increased from $73.4 \%$ for $0.2 \mathrm{M}$ to $95.4 \%$ for $1.6 \mathrm{M}$. This result is expected, as low vanadium concentrations induce mass transfer resistances that
Table 2. Charge-discharge performances including the electrolyte utilization efficiency EU (for the charging) of the solar VRFB using different vanadium concentrations at an illumination intensity of $300 \mathrm{~mW} \mathrm{~cm}^{-2}$.

\begin{tabular}{|c|c|c|c|c|}
\hline $\begin{array}{l}\text { Vanadium } \\
\text { concentration } \\
{\left[\mathrm{mol} \mathrm{l}^{-1}\right]}\end{array}$ & $\begin{array}{l}\mathrm{CE} \\
{[\%]}\end{array}$ & $\begin{array}{l}\mathrm{VE} \\
{[\%]}\end{array}$ & $\begin{array}{l}\mathrm{EE} \\
{[\%]}\end{array}$ & $\begin{array}{l}\text { Electrolyte } \\
\text { utilization } \\
\text { EU }[\%]\end{array}$ \\
\hline 0.2 & 78.4 & 73.4 & 57.5 & 87.0 \\
\hline 0.5 & 82.3 & 80.7 & 66.4 & 96.4 \\
\hline 1.0 & 80.6 & 86.6 & 69.8 & 97.1 \\
\hline 1.6 & 81.3 & 95.4 & 77.5 & 98.6 \\
\hline
\end{tabular}

contribute to voltage losses and consequently to lower VE and EE values, respectively [45]. From table 2, it becomes apparent that the solar VRFB using 1.6 M concentrated vanadium electrolytes performs best and can reach an energy efficiency of $77.5 \%$, which is among the highest values for VRFBs presented in the literature $[10,46]$. As can be seen from figure 5, the solar VRFB utilizing 1.6 M vanadium solutions reaches a bias-free charging time of approx. $9 \mathrm{~h}$, which implies a storage capacity of $21.15 \mathrm{Ah} \mathrm{l}^{-1}$ for each of the $5 \mathrm{ml}$ electrolyte compartments. This results in an excellent electrolyte utilization efficiency of $98.6 \%$ (for charging), which was the highest for all investigated VRFBs (see last column of table 2).

Besides the efficiency values, the applicability of the presented approach is also an important parameter. In fact, $9 \mathrm{~h}$ of solar charging is practically feasible when referring to the average annual sunlight hours per day in many regions of the world, e.g. California with 9:09h [47]. The power density

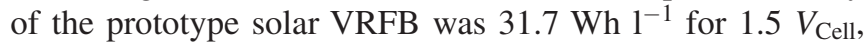
i.e. $317 \mathrm{mWh}$ for $10 \mathrm{ml}$ of electrolyte. Considering a typical household with an average electricity consumption of $8 \mathrm{kWh}$ per day, the presented device is obviously still far away from practical application. Therefore, from an engineering point of view, advances in cost-effective upscaling approaches for the concentrated photovoltaic and the battery system need to be undertaken [48, 49]. From a more scientific point of view, further attention should be devoted to studies on the long-term stability of the solar VRFB. This will be achieved, for instance, by controlling the potentials of the anolyte and catholyte compartments during prolonged cycling tests, while assessing the membrane properties in more detail. The stability of the investigated battery system has been assessed in [27], showing the excellent durability of the employed rayon-based carbon felt electrodes (see section 2.1). Thin-film silicon based solar cells suffer from light-induced degradation (LID), which needs to be taken into account for long-term solar battery operations. The effect of LID on the herein tested triple junction TF solar cell was investigated in detail in [50], showing a 13\% decrease of the initial solar cell efficiency after $1000 \mathrm{~h}$ of operation. Furthermore, parameters such as electrolyte temperature, $\mathrm{H}_{2} \mathrm{SO}_{4}$ concentration, electrolyte flow rate, additives in the electrolyte, and membrane surface and pore size aspect ratio can significantly influence the performance and stability of VRFBs [43, 44, 51-53].

For the successful application of the solar VRFB concept in a commercial system or product, the final metric of viability is the cost of the electricity produced. Several studies 


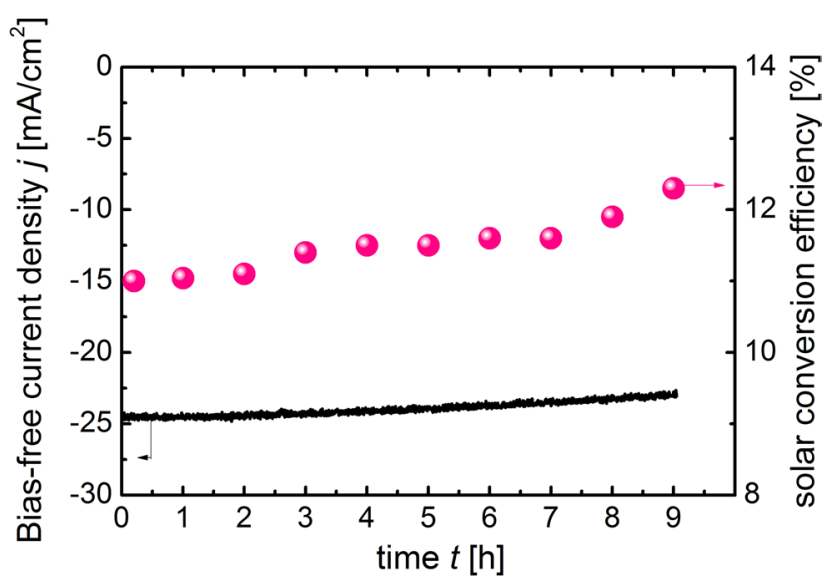

Figure 6. Left $y$-axis: bias-free current density for the solar charging of the $1.6 \mathrm{M}$ vanadium electrolyte at $300 \mathrm{~mW} \mathrm{~cm}{ }^{-2}$ illumination intensity over the charging time. Right $y$-axis: solar conversion efficiency over the charging time based on the bias-free charging current and the complete VRFB cell potential plotted in figure 5 for the $1.6 \mathrm{M}$ vanadium solution.

addressed the costs and life-cycle analysis and compared them for technologies aiming at solar energy storage and conversion concepts [54-56]. These studies show that, among others, the conversion efficiency is the most sensitive parameter to lower the cost of the produced electricity or fuel. For the presented solar battery, the solar conversion efficiency, i.e. the efficiency of the solar energy into chemical energy conversion for the solar charging process, can be assessed according to the evaluation presented in the Supplementary Information. A maximum solar conversion efficiency of $12.3 \%$ was measured for the $1.6 \mathrm{M}$ solar VRFB device at $300 \mathrm{~mW} \mathrm{~cm}^{-2}$ illumination intensity, as shown in figure 6.

Referring to a recently published review article [57], this value is the highest ever reported for unassisted solar charging of RFBs. It is, however, important to highlight that this efficiency value only accounts for the charging process and not for the complete round trip of the solar battery. The complete round trip solar-to-electricity efficiency for the solar VRFB can be assessed by using the EE value of the VRFB system and the electrical conversion efficiency of the solar cell, i.e. $77.5 \%$ and $13.5 \%$ (at $300 \mathrm{~mW} \mathrm{~cm}^{-2}$, see figure $\mathrm{S} 1$ ), resulting in an efficiency of $10.46 \%$ for the overall solar-to-electricity conversion process. This value is for state-of-the-art solar

fuel cell devices, which can store around $10 \%$ of solar energy into hydrogen [22], for instance, which in a second step is converted into electricity by a fuel cell operating at $60 \%$ efficiency. The round trip efficiency for this approach will be around $6 \%$. As both technologies produce electricity at similar costs $\left(<6 \mathrm{c} € \mathrm{~kW}^{-1}\right)$, it can be concluded that the solar VRFB approach offers a very attractive alternative to systems producing electricity through solar fuel conversion in fuel cells.

These examples outline the viability of the proposed solar battery concept regarding novel energy storage and conversion technologies. The presented prototype device therefore may pave the way for future lines of work, which will be needed to address efficiency improvements and techno-economical questions while assessing cost competitiveness.

\section{Conclusion}

In this study, we developed a prototype solar-driven vanadium redox-flow battery using concentrated TF silicon photovoltaics for efficient photoelectrochemical energy storage and conversion. The device was optimized regarding the membrane used, the vanadium concentration in the electrolyte, and the applied current density, i.e. illumination intensity. The bias-free solar battery device could reach storage capacities of up to $21.15 \mathrm{Ah}$ $1^{-1}$ paired with excellent energy efficiencies of up to $77.5 \%$ for the complete charge-discharge process. An overall solar-toelectricity efficiency of $10.46 \%$ was achieved, demonstrating the potential of the presented solar VRFB concept as a viable alternative for photoelectrochemical energy storage and conversion.

\section{Acknowledgments}

We thank S Moll for his contribution in the deposition of TF silicon solar cells. The authors from IREC thank Generalitat de Catalunya for financial support through the CERCA Program and M2E (2017SGR1246). IREC also acknowledges support by the European Regional Development Funds (ERDF, FEDER) and by MINECO project ENE2016-80788-C5-5-R and RESOL ENE2017-85087. SM-L thanks the European Union's Horizon 2020 and the Agency for Business Competitiveness of the Government of Catalonia for funding under the Marie SklodowskaCurie grant agreement No. 712939 (TECNIOspring PLUS). FU acknowledges financial support from MINECO through the Juan de la Cierva fellowship (FJCI-2016-29147) and NN acknowledges the support from the KIC InnoEnergy Masters programme. VS, KW, and FF (authors from IEK-5) thank the Deutsche Forschungsgemeinschaft (DFG) (Priority Program SPP 1613).

\section{Competing financial interests}

The authors declare no competing financial interests.

\section{Contributions}

FU, JRM, SML, CF and TA conceived the project and designed the experiments. FU and NN carried out the experiments. VS, KW and FF performed the deposition of the TF silicon solar cells. FU, JRM, and SML interpreted data. FU wrote the manuscript. All authors participated in discussions and contributed to the editing of the manuscript.

\section{ORCID iDs}

Félix Urbain (1) https://orcid.org/0000-0001-5423-6818

Teresa Andreu (1) https://orcid.org/0000-0002-2804-4545

\section{References}

[1] Ardo S et al 2018 Energy Environ. Sci. accepted (https://doi. org/10.1039/C7EE03639F) 
[2] Cheng W-H, Richter M H, May M M, Ohlmann J, Lackner D, Dimroth F, Hannappel T, Atwater H A and Lewerenz H-J 2018 ACS Energy Lett. 3 1795-800

[3] Urbain F et al 2014 Int. J. Photoenergy 2014249317

[4] Schreier M, Héroguel F, Steier L, Ahmad S, Luterbacher J S, Mayer M T, Luo J and Grätzel M 2018 Nat. Energy 217087

[5] Urbain F, Tang P, Carretero N M, Andreu T, Gerling L G, Voz C, Arbiol J and Morante J R 2017 Energy Environ. Sci. $102256-66$

[6] Leung P, Shah A A, Sanz L, Flox C, Morante J R, Xu Q, Mohamed M R, de León C P and Walsh F C 2017 J. Power Sources $360243-83$

[7] Alotto P, Guarnieri M and Moro F 2014 Ren. Sustain. Energy Rev. 29 325-35

[8] Flox C, Skoumal M, Rubio-Garcia J, Andreu T and Morante J R 2013 Appl. Energy 100 344-52

[9] Soloveichik G L 2015 Chem. Rev. 115 11533-58

[10] Cunha A, Martins J, Rodrigues N and Brito F P 2014 Int. J. Energy Res. 39 889-918

[11] Sum E and Skyllas-Kazacos M 1985 J. Power Sources 15179

[12] Skyllas-Kazacos M, Rychcik M and Robins R $1986 \mathrm{~J}$. Electrochem. Soc. $\mathbf{1 3 3} 1057$

[13] Rydh C J 1999 J. Power Sources 80 21-9

[14] Winsberg J, Hagemann T, Janoschka T, Hager M D and Schuber U S 2017 Angew. Chem., Int. Ed. Engl. 16 686-711

[15] Azevedo J, Seipp T, Burfeind J, Sousa C, Bentien A, Araújo J P and Mendes A 2016 Nano Energy 22 396-405

[16] Wei Z, Liu D, Hsu C and Liu F 2014 Electrochem. Commun. 45 79-82

[17] Wei Z, Shen Y, Liu D and Liu F 2017 Sci. Rep. 7629

[18] Green M A, Hishikawa Y, Dunlop E D, Levi D H, HohlEbinger J and Ho-Baillie A W Y 2017 Prog. Photovolt., Res. Appl. 26 3-12

[19] Taguchi M, Yano A, Tohoda S, Matsuyama K, Nakamura Y, Nishiwaki T, Fujita K and Maruyama E 2014 IEEE J. Photovolt. 4 96-9

[20] Lambertz A, Finger F, Schroop R E I, Rau U and Smirnov V 2015 Prog. Photovolt., Res. Appl. 23 939-48

[21] Ziegler J, Kaiser B, Jaegermann W, Urbain F, Becker J-P, Smirnov V and Finger F 2014 ChemPhysChem 15 4026-31

[22] Urbain F, Smirnov V, Becker J-P, Lambertz A, Yang F, Ziegler J, Kaiser B, Jaegermann W, Rau U and Finger F 2016 Energy Environ. Sci. 9 145-54

[23] Olson J M, Friedman D J and Kurtz S 2005 Handbook of Photovoltaic Science and Engineering ch 9, pp 359-411

[24] Geisz J F, Steiner M A, García I, Kurtz S R and Friedman D J 2013 Appl. Phys. Lett. 103041118

[25] Roe S, Menictas C and Skyllas-Kazacos M 2016 J. Electrochem. Soc. 163 A5023-8

[26] Böttler W, Smirnov V, Hüpkes J and Finger F 2012 Phys. Status Solidi A 209 1144-9

[27] Vázquez-Galván J, Flox C, Fàbrega C, Ventosa E, Parra A, Andreu T and Morante J R 2017 ChemSusChem 9 2089-98

[28] Hosseini M G, Mousavihashemi S, Murcia-López S, Flox C, Andreu T and Morante J R 2018 Carbon 136 444-53

[29] Edgar Ventosa E, Skoumal M, Vázquez F J, Flox C and Morante J R 2014 J. Power Sources 271 556-60
[30] Irtem E, Andreu T, Parra A, Hernandez-Alonso M D, GarciaRodriguez S, Riesco-Garcia J M, Penelas-Pérez G and Morante J R 2016 J. Mater. Chem. A 35 13582-8

[31] Irtem E, Hernández-Alonso M D, Parra A, Fàbrega C, Penelas-Pérez G, Morante J R and Andreu T 2017 Electrochim. Acta 240 225-30

[32] Wang K, Zhang Y, Liu L, Xi J, Wu Z and Qiu X 2018 Electrochim. Acta 259 11-9

[33] Jiang B, Wu L, Yu L, Qiu X and Xi J 2016 J. Membr. Sci. $51018-26$

[34] Hwang G-J, Kim S-W, In D-M, Lee D-Y and Ryu C-H 2018 J. Ind. Eng. Chem. $60360-5$

[35] Intan N N, Klyukin K, Zimudz T J, Hickner M A and Alexandrov V 2018 J. Power Sources 373 150-60

[36] Vrána J, Charvát J, Mazúr P, Bělský P, Dundálek J, Pocedič J and Kosek J 2018 J. Membr. Sci. 552 202-12

[37] Prifti H, Parasuraman A, Winardi S, Lim T M and SkyllasKazacos M 2012 Membranes 2 275-306

[38] Sevda S, Dominguez-Benetton X, Vanbroekhoven K, Sreekrishnan T R and Pant D 2013 Chem. Eng. J. 228 1-11

[39] Royne A, Dey C J and Mills D R 2005 Sol. Energy Mater. Sol. Cells 86 451-83

[40] Saloux E, Teyssedou A and Sorin M 2011 Solar Energy $85713-22$

[41] Würfel P and Würfel U 2016 Physics of Solar Cells: from Basic Principles to Advanced Concepts

[42] Urbain F et al 2016 Mater. Sci. Semicond. Proc. 42 142-6

[43] Kazacos M, Cheng M and Skyllas-Kazacos M 1990 J. Appl. Electrochem. 20 463-7

[44] Rahman F and Skyllas-Kazacos M 1998 J. Power Sources 72 105-10

[45] Skyllas-Kazacos M, Cao L, Kazacos M, Kausar N and Mousa A 2016 ChemSusChem 9 1-24

[46] Xu Q, Ji Y N, Qin L Y, Leung P K, Qiao F, Li Y S and Su H N 2018 J. Energy Storage 16 108-15

[47] www.climatemps.com/

[48] Becker J-P, Turan B, Smirnov V, Welter K, Urbain F, Wolff J, Haas S and Finger F 2017 J. Mater. Chem. A 5 4818-26

[49] Turan B, Becker J-P, Urbain F, Finger F, Rau U and Haas S 2016 Nat. Commun. 712681

[50] Urbain F, Smirnov V, Becker J-P and Finger F 2016 ACS Omega $1832-6$

[51] Kim D K, Yoon S J, Lee J and Kim S 2018 Appl. Energy 228 891-901

[52] Zhang J, Li L, Nie B, Vijayakumar M, Kim S, Wang W, Schwenzer B, Liu J and Yang Z $2011 \mathrm{~J}$. Appl. Electrochem. 41 1215-21

[53] Li X, Zhang H, Mai Z, Zhang H and Vankelecom I 2011 Energy Environ. Sci. 4 1147-60

[54] Zakeri B and Syri S 2015 Ren. Sus. Energy Rev. 42 569-96

[55] Yu M, McCulloch W D, Huang Z, Trang B B, Lu J, Amine K and Wu Y 2016 J. Mater. Chem. A 8 2766-82

[56] Herron J A, Kim J, Upadhye A A, Huber G W and Maravelias C T 2015 Energy Environ. Sci. 1 126-57

[57] Wedege K, Bae D, Drazevic E, Mendes A, Vesborg P C K and Bentien A 2018 RSC Adv. 8 6331-40 